\title{
A Study on the Concept of Employees Customer Orien- tation and its Impact on Competence Development
}

\author{
Thaya Madhavi* and Rajesh Mehrotra \\ School of Business and Management, Jaipur National University, Jaipur-302017, Rajasthan (State), India \\ *Corresponding author E-mail:madhavimbabit@gmail.com
}

\begin{abstract}
It is thought world over that customer orientation of employees needs to corporate success. It constitutes the major element of customer service thrown open by customer oriented service personnel to decide upon the great success of the business firm. Customer oriented service personnel are bestowed with communication, technical, problem solving skills, personality traits and commitment. Anticipating customer wishes and these in advance, and to act accordingly by customer oriented service personnel is a pivotal factor for the progress of an organization. This paper intends to study the concept of operational level employees orientation towards customers and its implication for competence development.
\end{abstract}

Keywords: Competence Development; Customer Orientation; Customer Oriented Service, Employees; Implication.

\section{Introduction}

Customer orientation is a long drawn plan in a lean business model, encouraging management and employees to keep pace with the changing wants and deeds of its customers. The company vide philosophy should be centered on fulfillment of customer wants and needs and that also should be viewed as the first priority of the company.

The selling companies very well know that customer needs and wants are changing from time to time. To cite an example, it is noticed that in 1990's, the consumers were purchasing desktop computers for their use. However, in 2000's these desktops have been replaced by laptops with the development of technology and in 2010's the same are occupied by tablets, phones and other smaller electronic devices. The retailers are always looking for customers to provide them the latest products as otherwise it would be difficult for retailers to prosper in the business. In the companies following a strategy of high price and facing vigorous competition, the performance of sales associates is best [1].

In the customer orientation field retailers take the lead to satisfy the customers by fulfilling their requirements. Retailers always monitor standards of products and maintain customer relationship to their satisfaction. Orientation of customers amplifies the link between emotive commitment and satisfaction of customers [2]. They always oblige to meet the client's needs and expectations pertaining to the product and services in the business arena. Some, such business strategies that relate to customer orientation include: generating a quality product mostly wanted by customers, immediate response and prompt service are the basic requirement wanted, redressal of consumer complaints and queries on war footing, responding community issues and other delicate matters with sense of responsibility.

\section{Review of Literature}

Many marketing theorists exist. Among those marketing theorists who focus their attention on customers usually act in a manner that is customer oriented; achieve more desirable results than other companies who do not [3]. Investigation made by [4], [5] support academic prospective of orientation of customers of a company. High level of interaction with customers, impalpable nature of services and integrated orientation of customers is anticipated to depict a vital part for the service companies economic success.

Researchers [6], [7] have surveyed the part played by operational level employees in the direction of quality service. Further, the studies conducted by [3], [8-10], have unmistakably addressed the customer orientation concept of operational level employees. As far as research in quality of service quality research is concerned, it was made known that conduct of employees undermines the discernment of the service. It was further pointed out by the researchers that the customers service quality is influenced by employee related aspects of the service assessment as in the case of [6] in whose research, three out of five service quality dimensions have direct or indirect impact on the conduct of employees (i.e., responsiveness, assurance and empathy).

Researcher [7] has recognized the comfort and personal attention provided to the employees that has required service quality components. Author [8] emphasized that the forefront employees plays an important role for business success of an organization. His research study constructs COSE which includes organizational constructs such as the organizational climate, socialization and personal construction verified as motivational effort and direction.

The author [9] have interpreted course as a tendency of the individual to encounter customer needs in an "on the job context". It covers a dimension that wishes of customers are fulfilled as be- 
lieved by employees. The second factor proposes the stretch to which employee can satisfy the interaction with customer. Researcher [3] based on the findings of [9], has adopted the meaning of customer orientation of service employees. Contradicting [9] they have argued that customer orientation works on five dimensions as "need to pamper" "need to read the customer", "need for personal relationship", "need to deliver" and "need to communicate". The ingenuity of jobs and orientation of customers abates the dissension of role and internal and external role accomplishment of employees [11].

At the end, [10] defined customer orientation of service employees as that of employees behavior in person to person interaction who have suggested three dimensional approach for Customer Orientation of service employees (COSE). During employee consumer interaction the customer needs are identified and accordingly the approach is based on the requirements of the customer needs. The COSE can thus be defined as the behavior of employees in their personal interaction with the customers to meet their needs.

On the part of skills dimensions of COSE, the authors have proposed the employees technical skills and social skills to form a separate part of dimensions of COSE. The social skills concept is focused on service employees capacity to take into consideration consumers perception throughout interaction [12-14]. Their perception visualizes factors such as visually (i.e., employees visual observance and understanding of what the consumer looks at and observes), cognitively (i.e., employee judges his understanding of how the consumer feels) [15]. So, all these facets are required to perceive the needs of customer to fulfill. Here technical skills are ranged separately from social skills to project in the research concept.

\section{Objectives of The Study}

1. To identify the competencies required for the employees.

2. To find the relationship between competencies and employees customer orientation.

3. To identify the association between demographic factors and their customer orientation

\subsection{Research Methodology}

The present research paper is an empirical one. Primary and the Secondary data have been collected for this study. The primary data were gathered through questionnaire pertaining to competencies of operational level employees towards customer orientation in Departmental stores. The secondary data was collected through books, journals, articles and internet.

Sample size and techniques: Random sampling method was used to collect the response from the three Departmental stores in Jaipur by the researcher. The sample size of the employees taken was 300 from all the three retail shops.

\subsection{Analysis and Discussion}

After reviewing National and International literature pertaining to the Competencies of operational level employees and their orientation towards customers the researcher intended to relate the competencies of employees and customer orientation in selected Departmental stores. The researcher revealed that there prevail a parametric association between competencies and customer orientation and demographic factors also play an important role in customer orientation. The data was analysed through SPSS software.

Table 1: Case Processing Summary

\begin{tabular}{|c|c|c|c|}
\hline & & $\mathrm{N}$ & $\%$ \\
\hline \multirow{3}{*}{ Cases } & Valid & 299 & 99.7 \\
\hline & Excluded $^{\mathrm{a}}$ & 1 & 0.3 \\
\hline & Total & 300 & 100.0 \\
\hline
\end{tabular}

${ }^{\mathrm{a}}$ Listwise deletion based on all variables in the procedure.

Table 2: Reliability Statistics

\begin{tabular}{|c|c|c|}
\hline $\begin{array}{c}\text { Cronbach's } \\
\text { Alpha }\end{array}$ & $\begin{array}{c}\text { Cronbach's Alpha Based on Stand- } \\
\text { ardized Items }\end{array}$ & $\begin{array}{c}\text { N of } \\
\text { Items }\end{array}$ \\
\hline 0.968 & 0.968 & 36 \\
\hline
\end{tabular}

Cronbach's Alpha test showed the significant value of 0.968 for all the items taken for the study as shown in the above tables. 1 and 2 .

\subsection{Demographic frequency distribution tables.}

The first column in the table. 3 lists the variables which are assigned 1 for male and 2 for female. The frequency of each score is displayed in the frequency column. This shows that of the 300 employees 201 were men and 99 were women, which constitutes $67 \%$ of men and $33 \%$ of women.

The first column in the table. 4 lists the variables where the age of employees is less than 20 years (1), 21-30 years (2), 31-40 years (3), 41-50 years (4) and 51-60 years (5). The frequency of each score is displayed in the frequency column. The survey shows that out of the 300 employees first group includes 27 i.e. employees having less than 20 years, 204 belongs to the second group i.e., 21-30 years, 53 belong to third category i.e., 31-40 years, 14 belonged to fourth category i.e., 41-50 years and 2 belonged to the fifth category i.e., 51-60 years employees which constitutes 9\%, $68 \%, 17.7 \%, 4.7 \%$ and $0.7 \%$ of employees respectively.

Table 3: Gender

\begin{tabular}{|c|c|c|c|c|c|}
\hline \multicolumn{2}{|c|}{} & Frequency & Percent & $\begin{array}{c}\text { Valid Per- } \\
\text { cent }\end{array}$ & $\begin{array}{c}\text { Cumulative } \\
\text { Percent }\end{array}$ \\
\hline \multirow{3}{*}{ Valid } & 1 & 201 & 67.0 & 67.0 & 67.0 \\
\cline { 2 - 6 } & 2 & 99 & 33.0 & 33.0 & 100.0 \\
\cline { 2 - 6 } & Total & 300 & 100.0 & 100.0 & \\
\hline
\end{tabular}

Table 4: Age

\begin{tabular}{|c|c|c|c|c|c|}
\hline \multicolumn{2}{|c|}{} & Frequency & Percent & Valid Percent & Cumulative Percent \\
\hline \multirow{4}{*}{ Valid } & 1 & 27 & 9.0 & 9.0 & 9.0 \\
\cline { 2 - 6 } & 2 & 204 & 68.0 & 68.0 & 77.0 \\
\cline { 2 - 6 } & 3 & 53 & 17.7 & 17.7 & 94.7 \\
\cline { 2 - 6 } & 4 & 14 & 4.7 & 4.7 & 99.3 \\
\cline { 2 - 6 } & 5 & 2 & 0.7 & 0.7 & 100.0 \\
\hline
\end{tabular}

The first column in the table. 5 lists the variables where 1 stands for matriculation, 2 stands for intermediate, 3 stands for graduation, 4 stands for post graduation ad 5 stands for others. The frequency of each score is displayed in the frequency column. This shows that of the 300 employees 42 belonged to the first category, 102 belonged to the second category, 140 belonged to the third category, 11 belonged to the fourth category and 5 belonged to the fifth category of employees which constitute 14\%, 34\%, 46.7\%, $3.7 \%$ and $1.7 \%$ of employees respectively.

Table 5: Education

\begin{tabular}{|c|c|c|c|c|c|}
\hline \multicolumn{2}{|c|}{} & Frequency & Percent & $\begin{array}{c}\text { Valid } \\
\text { Percent }\end{array}$ & $\begin{array}{c}\text { Cumulative } \\
\text { Percent }\end{array}$ \\
\hline \multirow{4}{*}{ Valid } & 1 & 42 & 14.0 & 14.0 & 14.0 \\
\cline { 2 - 6 } & 2 & 102 & 34.0 & 34.0 & 48.0 \\
\cline { 2 - 6 } & 3 & 140 & 46.7 & 46.7 & 94.7 \\
\cline { 2 - 6 } & 4 & 11 & 3.7 & 3.7 & 98.3 \\
\cline { 2 - 6 } & 5 & 5 & 1.7 & 1.7 & 100.0 \\
\cline { 2 - 6 } & Total & 300 & 100.0 & 100.0 & \\
\hline
\end{tabular}

The first column lists in the table. 6 the variables where 1 stands for less than Rs. 10,000, 2 stands for Rs. 10,001-Rs. 20,000, 3 stands for Rs. 20,001-Rs. 40,000 and 4 stands for Rs.40, 001-Rs 60,000 . The frequency of each score is displayed in the frequency column. This depicts that out of the 300 employees 129 belonged to the 1st category (Rs. 10,000), 115 belongs to the 2 nd variable (Rs. 10,001-Rs. 20,000), 42 belonged to the 3rd category (Rs. 20,001-Rs. 40,000), 14 belongs to the 4 th variable (Rs.40, 001-Rs $60,000)$ of employees which constitute $43 \%, 38.3 \%, 14 \%$ and $4.7 \%$ of employees respectively. 
Table 6: Monthly Income

\begin{tabular}{|c|c|c|c|c|c|}
\hline \multicolumn{2}{|c|}{} & Frequency & Percent & $\begin{array}{c}\text { Valid } \\
\text { Percent }\end{array}$ & $\begin{array}{c}\text { Cumulative } \\
\text { Percent }\end{array}$ \\
\hline \multirow{4}{*}{ Valid } & 1 & 129 & 43.0 & 43.0 & 43.0 \\
\cline { 2 - 6 } & 2 & 115 & 38.3 & 38.3 & 81.3 \\
\cline { 2 - 6 } & 3 & 42 & 14.0 & 14.0 & 95.3 \\
\cline { 2 - 6 } & 4 & 14 & 4.7 & 4.7 & 100.0 \\
\cline { 2 - 6 } & Total & 300 & 100.0 & 100.0 & \\
\hline
\end{tabular}

The first column lists in the table. 7 the variables where 1 stands for rural, 2 stands for semi-urban and 3 stands for urban. The frequency of each score is displayed in the frequency column. This shows out of 300 employees 64 employees reside in rural areas which constitute $21.3 \%, 100$ employees reside in semi-urban areas which constitute $33.3 \%$ and 136 employees reside in urban areas which constitute $45.3 \%$.

Table 7: Residence

\begin{tabular}{|c|c|c|c|c|c|}
\hline \multicolumn{2}{|c|}{} & Frequency & Percent & $\begin{array}{c}\text { Valid } \\
\text { Percent }\end{array}$ & $\begin{array}{c}\text { Cumulative } \\
\text { Percent }\end{array}$ \\
\hline \multirow{4}{*}{ Valid } & 1 & 64 & 21.3 & 21.3 & 21.3 \\
\cline { 2 - 6 } & 2 & 100 & 33.3 & 33.3 & 54.7 \\
\cline { 2 - 6 } & 3 & 136 & 45.3 & 45.3 & 99.7 \\
\cline { 2 - 6 } & Total & 300 & 100.0 & 100.0 & 100.0 \\
\hline
\end{tabular}

The first column lists in the table. 8 variables where 1 stands for 0 2 years of experience, 2 stands for 2.1- 4 years of experience of employees, 3 stands for 4.1-6 years of employees experience, 4 stands for 6.1-8 years of employees experience and 5 stands for above 8 years of experience. Out of 300 employees 111 employees have experience between 0-2 years which represents $37 \%, 70$ employees have experience up to 4 years that represents $23.3 \%, 51$ employees have experience up to 6 years of experience which represents $17 \%, 22$ employees have experience up to 8 years of experience which represents $7.3 \%$ and finally 46 employees have a total experience of above 8 years which represents $15.3 \%$.

Table 8: Total Experience

\begin{tabular}{|c|c|c|c|c|c|}
\hline \multicolumn{2}{|c|}{} & Frequency & Percent & $\begin{array}{c}\text { Valid } \\
\text { Percent }\end{array}$ & $\begin{array}{c}\text { Cumulative } \\
\text { Percent }\end{array}$ \\
\hline \multirow{4}{*}{ Valid } & 1 & 111 & 37.0 & 37.0 & 37.0 \\
\cline { 2 - 6 } & 2 & 70 & 23.3 & 23.3 & 60.3 \\
\cline { 2 - 6 } & 3 & 51 & 17.0 & 17.0 & 77.3 \\
\cline { 2 - 6 } & 4 & 22 & 7.3 & 7.3 & 84.7 \\
\cline { 2 - 6 } & 5 & 46 & 15.3 & 15.3 & 100.0 \\
\cline { 2 - 6 } & Total & 300 & 100.0 & 100.0 & \\
\hline
\end{tabular}

Table 9: Experience in Present Retail Store

\begin{tabular}{|c|c|c|c|c|c|}
\hline \multicolumn{2}{|c|}{ Table 9: Experience in Present Retail Store } \\
\hline \multirow{2}{*}{} & Frequency & Percent & $\begin{array}{c}\text { Valid } \\
\text { Percent }\end{array}$ & $\begin{array}{c}\text { Cumulative } \\
\text { Percent }\end{array}$ \\
\hline \multirow{4}{*}{ Valid } & 1 & 183 & 61.0 & 61.0 & 61.0 \\
\cline { 2 - 6 } & 2 & 68 & 22.7 & 22.7 & 83.7 \\
\cline { 2 - 6 } & 3 & 12 & 4.0 & 4.0 & 87.7 \\
\cline { 2 - 6 } & 4 & 9 & 3.0 & 3.0 & 90.7 \\
\cline { 2 - 6 } & 5 & 28 & 9.3 & 9.3 & 100.0 \\
\cline { 2 - 6 } & Total & 300 & 100.0 & 100.0 & \\
\hline
\end{tabular}

The first column lists in the table. 9 variables where 1 stands for 0 2 years of experience, 2 stands for 2.1- 4 years of experience of employees, 3 stands for 4.1-6 years of employees experience, 4 stands for 6.1-8 years of employees experience and 5 stands for above 8 years of experience. Out of 300 employees 183 employees have experience between $0-2$ years which represents $61 \%, 68$ employees have experience up to 4 years that represents $22.7 \%, 12$ employees have experience up to 6 years of experience which represents $4 \%, 9$ employees have experience up to 8 years of experience which represents $3 \%$ and finally 28 employees have a total experience of above 8 years which represents $9.3 \%$.

Table. 10 represent the outcomes of the descriptive statistics for mean and standard deviations of all the factors used. Most of the employees agree that they are active and good listeners as per the Mean but Standard Deviation shows that the results are a little wide spread when compared to others. Remaining Q 2, 3, 4 agree that employees are fluent in language, create friendly environment and clarifies the doubts of customers and as seen from the table standard deviation does not deflect much from mean. This survey depicts that there is relationship between employees communication skills and customer orientation.

Table 10: Mean and Standard Deviation of Communication

\begin{tabular}{|c|c|c|}
\hline Dimensions & Mean & Standard deviation \\
\hline Communication & & 1.02 \\
\hline Q 1 & 4.05 & 0.84 \\
\hline Q2 & 4.25 & 0.87 \\
\hline Q3 & 4.01 & 0.80 \\
\hline Q4 & 4.00 & \\
\hline
\end{tabular}

Table. 11 represent the outcomes of the descriptive statistics for mean and standard deviation for all the factors used. Most of the employees in Q 5, 6, 7, 8 agree that they can demonstrate required skills, troubleshoots problem easily, update their technical skills and agree that training is helpful in encouraging best talent as per the mean and standard deviation shows that the results are not much deflected from mean. This shows that there is relationship between employees technical skills and customer orientation in Departmental stores.

Table 11: Mean and Standard Deviation of Technical Skills

\begin{tabular}{|c|c|c|}
\hline Technical skills & Mean & Standard Deviation \\
\hline Q5 & 4.00 & 0.90 \\
\hline Q6 & 4.07 & 0.89 \\
\hline Q7 & 4.01 & 0.93 \\
\hline Q8 & 4.06 & 0.88 \\
\hline
\end{tabular}

Table. 12 represent the outcomes of the descriptive statistics for mean and standard deviation for all the factors used. Most of the employees agree that they are good at identifying problems in a timely manner, take steps to conflict situations, analyze the problems and make sound decisions according to mean except for Q12 and Q13. This shows that there is relationship between employees problem solving skills and customer orientation.

Table 12: Mean and Standard Deviation of Problem Solving

\begin{tabular}{|c|c|c|}
\hline Problem solving & Mean & Standard Deviation \\
\hline Q9 & 4.06 & 0.88 \\
\hline Q10 & 4.03 & 0.94 \\
\hline Q11 & 3.98 & 0.97 \\
\hline Q12 & 4.02 & 0.93 \\
\hline
\end{tabular}

Table 13: Mean and Standard Deviation of Personality

\begin{tabular}{|c|c|c|}
\hline Personality & Mean & Standard Deviation \\
\hline Q13 & 4.14 & 0.87 \\
\hline Q14 & 4.06 & 0.82 \\
\hline Q15 & 4.11 & 0.87 \\
\hline Q16 & 4.07 & 0.95 \\
\hline Q17 & 4.06 & 0.92 \\
\hline
\end{tabular}

Table. 13 represent the outcomes of the descriptive statistics for mean and standard deviation for all the factors used. Most of the employees agree that they are well organized in terms of dress code and appearance, energetic, confident and trustworthy, flexible, self developing as per the mean but standard deviation show slight deviation from mean in Q17 and Q18. This shows that there is relation between employees personality and orientation of customer.

Table. 14 represent the outcomes of the descriptive statistics of mean and standard deviation for all the factors used. Most of the employees agree that they inspire, motivate, are concerned about the opinion of customer and takes action without being asked as per the mean but standard deviation is much deflected when compared to others. This shows that there is less employees commitment towards customer orientation.

Table 14: Mean and Standard Deviation of Commitment

\begin{tabular}{|c|c|c|}
\hline Commitment & Mean & Standard Deviation \\
\hline Q18 & 4.07 & 0.95 \\
\hline Q19 & 3.98 & 0.92 \\
\hline Q20 & 3.91 & 1.11 \\
\hline Q21 & 3.89 & 1.04 \\
\hline
\end{tabular}




\subsection{T-Test for Gender}

The results of $\mathrm{T}$ test shown in table 15, that the difference of means with their respective standard deviations for male and female on orientation of customers are significant. It shows that there are difference of opinions between male and female found in the following statements. The $\mathrm{p}$ value is less than 0.005 for question numbers Q4, Q14, Q19, Q20 and Q22. That is the means are significantly different. For the remaining questions the $\mathrm{p}$ value is more than 0.05 which is, the means are not significantly different.

\subsection{ANOVA test for experience of employees}

The table 16 shown below is the test result of ANOVA. The test results shows that there are differences in the perception of employees at different level of experiences in the process orientation of customers. The employees of fourth category i.e., 6.1 to 8 years experience are showing more commitment to customers when compared to other categories. Therefore the degree of orientation as seen from the table is on high side. The mean values indicate that employees strongly agree that communication, technical, problem solving, personality and commitment plays and important role in satisfying the customers. Significance value is showing differences in Q2, Q3, Q4, Q6, Q7, Q8, Q9, Q10, Q12, Q14, Q17, $\mathrm{Q} 18, \mathrm{Q} 20$ and Q21. The more experience gained by employees the more would be orientation towards customers.

\section{Conclusion}

Customer orientation is an essential requirement for every organization to adopt for well-being of an organization and to meet the demands of customers by providing proper interaction with dedicated service employees. It is also defined as knowledge management. The service employees are bestowed with personal skills and technical skills which will help them to interact with customers that might ultimately leads to customer satisfaction [16-18]. Performance of small organizations is influenced by orientation of customers with an increase in creativity, chance taking and right set of circumstances [19].The organizations and firms would flourish well by implementing customer orientation devices in the business to catch the mights of customers, who often wants that their requirements are met with positive behavioral attitude of service employees. The output of encouraging efforts through incentives and job assessment is pivotal for employees orientation of customers [20].

Customer oriented organization keep the customer satisfaction on top priority to sustain in the present day competitive market. The latest up gradation of technology combined with delivery of quality products to the customers and well-mannered behavior of service employees can take the organization to the high level of economic success. The development of enterprise is related to innovative product only with the compatibility of orientation of customers which in return has a direct influence on company's achievement and new product [21].

The findings of this paper states that out of 300 respondents, operational level employees with regard to orientation of customers is an important driver for satisfaction of customers within the Departmental stores. Factors of employees orientation towards customer namely communication, technical skills, problem solving, personality and commitment, illustrate that especially the employees communication, technical, problem solving, personality develop a stable relationship with customers as it exhibits a strong impact on satisfaction and commitment[16], [19]. It was found that commitment of employees service is less when compared to other dimensions. Demographic factors such as age, gender, education, experience play an important role in customer satisfaction. Basis of corporate competence development is integrated customer- orientation where management of core competencies and development of competencies becomes essential for both internal and external business processes. The findings suggest that the level of commitment can be increased by a change in the policies, compensation and working conditions by the management.

\section{Scope for future research}

The study covers only departmental stores of Jaipur city and analysis was limited to T-test and ANOVA. It is recommended that broad study can be conducted in entire Rajasthan State with more tests like correlation and regression.

\section{References}

[1] Donavan, D. T., Brown, T. J. and Mowen, J. C. (2004), "Internal benefits of service worker-customer orientation: job satisfaction, commitment, and organizational citizenship behaviors", Journal of Marketing, vol. 68, no.1, pp. 128-146.

[2] Narver, J. C. and Slater, S. F. (1990), "The effect of a market orientation on business profitability", Journal of Marketing, vol. 54, pp. 20-35.

[3] Jaworski, B. J. and Kohli, A. K. (1993), "Market orientation: antecedents and consequences", Journal of Marketing, vol. 57, no. 3, pp. 53-70.

[4] Parasuraman, A., Zeithaml, V. A. and Berry, L. L. (1988), "SERVQUAL: a multiple-item scale for measuring consumer perceptions of service quality", Journal of Retailing, vol. 64, no.1, pp. $12-40$.

[5] Dabholkar, P. A., Sheperd, C. D. and Thorpe, D. I. (2000), “A comprehensive framework for service quality: an investigation of critical conceptual and measurement issues through a Longitudinal study", Journal of Retailing, vol. 76, no. 2, pp. 139-73

[6] Kelley, S. W. (1992), "Developing customer orientation among service employees", Journal of the Academy of Marketing Science, vol. 20 , no. 1 , pp. 27-36.

[7] Brown, T. J., Mowen, J. C., Donavan, D. T. and Licata, J. W. (2002), "The customer orientation of service workers: personality trait influences on self and supervisor performance ratings", Journal of Marketing Research, vol. 39, no. 1, pp. 110-19.

[8] Hening-Thurau, T. and Thurau, C. (2003). "Customer orientation of service employees-toward a conceptual framework of a key relationship marketing construct", Journal of Relationship Marketing, vol. 2 , no. 1 , pp. 1-32.

[9] Flavell, J.H., Botkin, P.T., Fry, C.L., Wright, J.W. and Jarvis, P.E. (1968), The Development of Role-taking and Communication Skills in Children, Wiley.

[10] Mead, G.H. (1934), Mind, Self and Society, University of Chicago Press, Chicago, IL.

[11] Khalili, H. Sameti, A. Sheybani, H. (2016)."A Study on the Effect of Empowerment on Customer Orientation of Employees", Global Business Review, vol. 17, no.1, pp. 38-50. https://doi.org/10.1177/ 0972150915610674

[12] Hening-Thurau, T. (2004). "Customer Orientation of service employees-Its impact on customer satisfaction, commitment and retention", International Journal of Service Industry Management, vol. 15, no. 5, pp.460-478. DOI10.1108/09564230419564939.

[13] Homburg, C. Muller, M.and Klarmann, M. (2011)."When Should the Customer Really Be King? On the optimum Level of Salesperson Customer orientation in Sales Encounters", Journal of Marketing, vol. 75. no. 2. pp.55-74.

[14] Kim, W.and Ok, C. (2010). "Customer Orientation of Service Employees and Rapport: Influences On Service-Outcome Variables in Full-Service Restaurants", Journal of Hospitality and Tourism Research, vol. 34, no. 1, pp. 34-55.

[15] Harram A, Fozia M (2015) Customer Oriented Marketing Capabilities and Firm Performance Mediated by New Product Development Capabilities and Moderated by Environmental Turbulence. Int $\mathrm{J}$ Econ Manag Sci 4:282. doi: 10.4172/21626359.1000282

[16] Varghese, J. Edward, M. (2018)."Relationship Between Job Orientation and Performance of Sales People: A Financial Services Industry Perspective", IIM Kozhikode Society \& Management Review, vol. 7, no. 1, pp. 88-96

[17] Daniel Korschun, D. Bhattacharya, C. B. and Swain, S. D. (2014) "Corporate Social Responsibility, Customer Orientation, and the 
Job Performance of Frontline Employees", Journal of Marketing, vol. 78, no. 3, pp. 20-37.

[18] Brockman, K. B. Jones, M. A. Becherer, R. C. (2012). "Custome Orientation and Performance in Small Firms: Examining the Moderating Influence of Risk-Taking, Innovativeness, and Opportunity Focus" Journal of Small Business Management, vol. 50, no. 3, pp. 429-446. https://doi.org/10.1111/ j.1540-627X.2012.00361.

[19] Yavas, U. Osman M Karatepe, O. M, Emin Babakus, E. (2011)."Do customer orientation and job resourcefulness moderate the impact of interrole conflicts on frontline employees' performance?", vol. 11 , no. 2 , pp. $148-159$.
[20] Thoumrungroje, A. and Racela, O. (2012). "The contingent role of customer orientation and entrepreneurial orientation on product innovation and performance", Journal of Strategic Marketing, vol. 21, no. 2, pp. 140-159. https://doi.org/10.1080/0965254X.2012.74212

[21] Gountas, S. Gountas, J. Mavondo, F. T. (2014). "Exploring the associations between standards for service delivery (organisational culture), co-worker support, self-efficacy, job satisfaction and customer orientation in the real estate industry", Australian Journal of Management, vol. 39, no. 1, pp. 107-126.

Table 15: T-TEST: Group Statistics

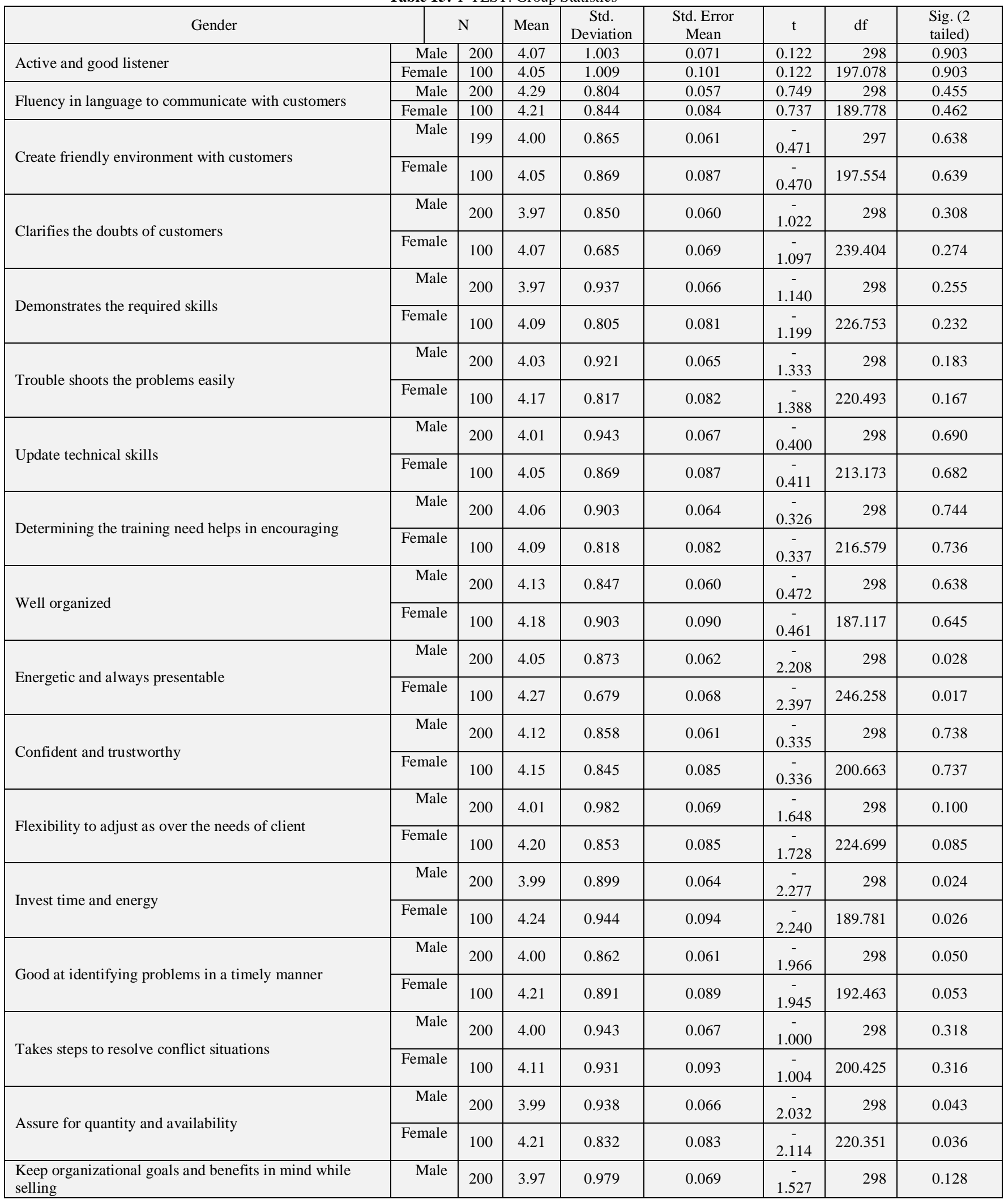




\begin{tabular}{|c|c|c|c|c|c|c|c|c|}
\hline & Female & 100 & 4.14 & 0.841 & 0.084 & $\begin{array}{c}- \\
1.606 \\
\end{array}$ & 226.791 & 0.110 \\
\hline \multirow{2}{*}{ Make sound, well informed decisions } & Male & 200 & 3.90 & 0.989 & 0.070 & $\begin{array}{c}- \\
2.539\end{array}$ & 298 & 0.012 \\
\hline & Female & 100 & 4.19 & 0.861 & 0.086 & $\begin{array}{c}- \\
2.659\end{array}$ & 224.249 & 0.008 \\
\hline \multirow{2}{*}{ Analyze and describe a problem } & Male & 200 & 4.00 & 0.975 & 0.069 & $\begin{array}{c}- \\
0.748 \\
\end{array}$ & 298 & 0.455 \\
\hline & Female & 100 & 4.08 & 0.825 & 0.082 & $\begin{array}{c}- \\
0.791\end{array}$ & 229.738 & 0.430 \\
\hline \multirow{2}{*}{ Take action without being asked } & Male & 200 & 3.88 & 1.147 & 0.081 & 0.626 & 298 & 0.531 \\
\hline & Female & 100 & 3.96 & 1.024 & 0.102 & $\begin{array}{c}- \\
0.651\end{array}$ & 219.244 & 0.516 \\
\hline \multirow{2}{*}{ Is proactive } & Male & 200 & 4.05 & 0.953 & 0.067 & $\begin{array}{c}- \\
1.342\end{array}$ & 298 & 0.181 \\
\hline & Female & 100 & 4.19 & 0.720 & 0.072 & $\begin{array}{c}- \\
1.470\end{array}$ & 251.951 & 0.143 \\
\hline \multirow{2}{*}{ Achieves goals beyond job requirements } & Male & 200 & 3.84 & 1.072 & 0.076 & $\begin{array}{c}- \\
1.175 \\
\end{array}$ & 298 & 0.241 \\
\hline & Female & 100 & 3.99 & 0.980 & 0.098 & $\begin{array}{c}- \\
1.211\end{array}$ & 214.841 & 0.227 \\
\hline
\end{tabular}

Table 16: ANOVA-TEST: Group Statistics

\begin{tabular}{|c|c|c|c|c|c|c|}
\hline & & Sum of Squares & df & Mean square & $\mathrm{F}$ & Sig. \\
\hline \multirow{3}{*}{ Active and good listener } & Between Groups & 18.001 & 4 & 4.5 & \multirow{3}{*}{4.692} & \multirow{3}{*}{0.001} \\
\hline & Within Groups & 282.919 & 295 & 0.959 & & \\
\hline & Total & 300.92 & 299 & & & \\
\hline \multirow[t]{2}{*}{ Fluency in language to communicate with customers } & Within Groups & 198 & 295 & 0.671 & \multirow{2}{*}{0.641} & \multirow{2}{*}{0.634} \\
\hline & Total & 199.72 & 299 & & & \\
\hline \multirow{3}{*}{ Create friendly environment with customers } & Between Groups & 3.03 & 4 & 0.757 & \multirow{3}{*}{1.013} & \multirow{3}{*}{0.401} \\
\hline & Within Groups & 219.886 & 294 & 0.748 & & \\
\hline & Total & 222.916 & 298 & & & \\
\hline \multirow{3}{*}{ Clarifies the doubts of customers } & Between Groups & 2.477 & 4 & 0.619 & \multirow{3}{*}{0.969} & \multirow{3}{*}{0.425} \\
\hline & Within Groups & 188.519 & 295 & 0.639 & & \\
\hline & Total & 190.997 & 299 & & & \\
\hline \multirow{3}{*}{ Demonstrates the required skills } & Between Groups & 8.203 & 4 & 2.051 & \multirow{3}{*}{2.61} & \multirow{3}{*}{0.036} \\
\hline & Within Groups & 231.784 & 295 & 0.786 & & \\
\hline & Total & 239.987 & 299 & & & \\
\hline \multirow{2}{*}{ Trouble shoots the problems easily } & Between Groups & 3.235 & 4 & 0.809 & \multirow{2}{*}{1.023} & \multirow{2}{*}{0.395} \\
\hline & Total & 236.387 & 299 & & & \\
\hline \multirow{3}{*}{ Update technical skills } & Between Groups & 6.886 & 4 & 1.722 & \multirow{3}{*}{2.073} & م ת \\
\hline & Within Groups & 244.994 & 295 & 0.83 & & 0.084 \\
\hline & Total & 251.88 & 299 & & & \\
\hline & Between Groups & 6.353 & 4 & 1.588 & & \\
\hline Determining the training need helps in encouraging & Within Groups & 222.314 & 295 & 0.754 & 2.108 & 0.08 \\
\hline & Total & 228.667 & 299 & & & \\
\hline & Between Groups & 6.163 & 4 & 1.541 & & \\
\hline Well organized & Within Groups & 217.384 & 295 & 0.737 & 2.091 & 0.082 \\
\hline & Total & 223.547 & 299 & & & \\
\hline & Between Groups & 2.68 & 4 & 0.67 & & 0400 \\
\hline Energetic and always presentable & Within Groups & 197.757 & 295 & 0.67 & 0.999 & 0.408 \\
\hline & Total & 200.437 & 299 & & & \\
\hline & Between Groups & 9.865 & 4 & 2.466 & & \\
\hline Confident and trustworthy & Within Groups & 207.321 & 295 & 0.703 & 3.509 & 0.008 \\
\hline & Total & 217.187 & 299 & & & \\
\hline & Total & 266.387 & 299 & & & \\
\hline & Between Groups & 14.19 & 4 & 3.548 & & \\
\hline Invest time and energy & Within Groups & 239.34 & 295 & 0.811 & 4.373 & 0.002 \\
\hline & Total & 253.53 & 299 & & & \\
\hline & Between Groups & 1.772 & 4 & 0.443 & & \\
\hline Good at identifying problems in a timely manner & Within Groups & 227.758 & 295 & 0.772 & 0.574 & 0.682 \\
\hline & Total & 229.53 & 299 & & & \\
\hline & Between Groups & 10.399 & 4 & 2.6 & 3078 & 0018 \\
\hline Takes steps to resolve conflict situations & Within Groups & 253.268 & 295 & 0.859 & 3.028 & 0.018 \\
\hline & Total & 263.667 & 299 & & & \\
\hline & Between Groups & 7.676 & 4 & 1.919 & & \\
\hline Assure for quantity and availability & Within Groups & 239.244 & 295 & 0.811 & 2.366 & 0.053 \\
\hline & Total & 246.92 & 299 & & & \\
\hline & Between Groups & 4.473 & 4 & 1.118 & 1.277 & 0.279 \\
\hline Keep organizational goals and benefits in mind while selling & Within Groups & 258.363 & 295 & 0.876 & & \\
\hline
\end{tabular}




\begin{tabular}{|c|c|c|c|c|c|c|}
\hline & Total & 262.837 & 299 & & & \\
\hline \multirow{3}{*}{ Make sound, well informed decisions } & Between Groups & 4.856 & 4 & 1.214 & \multirow{3}{*}{1.331} & \multirow{3}{*}{0.259} \\
\hline & Within Groups & 269.131 & 295 & 0.912 & & \\
\hline & Total & 273.987 & 299 & & & \\
\hline \multirow{3}{*}{ Analyze and describe a problem } & Between Groups & 7.951 & 4 & 1.988 & \multirow{3}{*}{2.356} & \multirow{3}{*}{0.054} \\
\hline & Within Groups & 248.885 & 295 & 0.844 & & \\
\hline & Total & 256.837 & 299 & & & \\
\hline \multirow{3}{*}{ Take action without being asked } & Between Groups & 5.788 & 4 & 1.447 & \multirow{3}{*}{1.184} & \multirow{3}{*}{0.318} \\
\hline & Within Groups & 360.408 & 295 & 1.222 & & \\
\hline & Total & 366.197 & 299 & & & \\
\hline \multirow{3}{*}{ Is proactive } & Between Groups & 1.887 & 4 & 0.472 & \multirow{3}{*}{0.601} & \multirow{3}{*}{0.662} \\
\hline & Within Groups & 231.499 & 295 & 0.785 & & \\
\hline & Total & 233.387 & 299 & & & \\
\hline \multirow{3}{*}{ Achieves goals beyond job requirements } & Between Groups & 3.083 & 4 & 0.771 & \multirow{3}{*}{0.705} & \multirow{3}{*}{0.589} \\
\hline & Within Groups & 322.287 & 295 & 1.092 & & \\
\hline & Total & 325.37 & 299 & & & \\
\hline
\end{tabular}

